\title{
CONSUMER BEHAVIOUR OF THE TRAVEL AGENCIES' CUSTOMERS IN THE SEGMENT OF SEASIDE HOLIDAY
}

\author{
[Spotřební chování zákazníků cestovních kanceláří segmentu pobytových \\ dovolených u moře]
}

\author{
Lena Malačka ${ }^{1}$, Jitka Veselá ${ }^{2}$ \\ ${ }^{1}$ Univerzita Tomášse Bati ve Zlíně, Fakulta managementu a ekonomiky, Mostní. 5139, 76000 Zlín \\ Email:malacka@fame.utb.cz \\ ${ }^{2}$ Soukromá vysoká škola ekonomická Znojmo s.r.o., Loucká 21, 66902 Znojmo \\ Email:vesela@svse.cz
}

\begin{abstract}
Presented paper deals with the topic of consumer behaviour of the travel agencies' customers and their specific requirements when they buy the seaside holiday. The research was conducted on the base of qualitative research and the method used in the research was focus groups. The Internet, word of mouth, social networks (as Facebook or Twitter) and TV commercials are mentioned as the most frequently used source of information which influence the most the customers opinion by both groups of respondents according to the result part. The examined groups do not have the same features in the area of holiday selection process. This topic is a relevant topic in comparison with authors all over the world and has the potential for future research.
\end{abstract}

Keywords: focus groups, promotion, promotional materials, qualitative research, tourism, travel agency.

JEL classification: L83, M31, M37

Doručeno redakci: 6.11.2017; Recenzováno: 16.11.2017; 20.11.2017; Schváleno k publikování: 13.12.2017

\section{Úvod}

V současnosti je možné v životním stylu lidí sledovat jisté trendy, které mají vliv nejen na životy těchto lidí, ale také na obchodníky, kteří se jim musí přizpůsobovat a měnit svoji nabídku dle aktuálních požadavků a preferencí svých zákazníků. Jedním z těchto trendů je i fakt, že lidé jsou vystavováni v nadměrném množství stresu a stresovým situacím, což vede k zhoršení jejich psychického stavu a narušení tzv. mentální hygieny. Proto stále častěji vyhledávají služby cestovních kanceláří a dalších subjektů cestovního ruchu, díky kterým mohou tyto nežádoucí jevy odbourávat.

Předkládaný př́spěvek se zabývá motivy zákazníků, které je vedou ke koupi produktů cestovního ruchu a také jejich spotřebními preferencemi, které ovlivňují jejich rozhodování o tom, zda si produkt koupí či si dovolenou zařídí vlastním silami, kde budou produkt nakupovat, kde a kdo hledá potřebné informace, které $\mathrm{z}$ nástrojů marketingové komunikace $\mathrm{k}$ získávání informací používají či jaké jsou faktory mající vliv na nákupní rozhodnutí.

Tyto informace jsou pro subjekty cestovního ruchu nepostradatelné. Pokud totiž dobře neznají svého zákazníka, nemohou mu připravit ani nabídku, která by ho oslovila, prŕípadně kterou by se rozhodl zakoupit.

Jak bude zmíněno $\mathrm{v}$ kapitole věnované metodice, byla $\mathrm{k}$ tomuto účelu využita metoda marketingového výzkumu Focus Groups, která je metodou kvalitativní. Nicméně z již provedených výzkumů (Surynek, Komárková a Kašparová 2001; Mráček, Veselá a Zich 2012; Zich a Veselá 2013) je patrné, že použití kvalitativních metod v oblasti "měkkých" věd tvoří 
nedílnou součást jak ve fázi získávání prvotních poznatků o daném tématu a sestavování prerekvizit výzkumu, tak i v dalších fázích výzkumu např. k ověřování výsledků získaných kvantitativním výzkumem.

\section{Literární rešerše}

Dle světové organizace cestovního ruchu (UNWTO Annual Report 2013, 2014) je cestovní ruch klíčovým odvětvím $\mathrm{v}$ řadě světových ekonomik, a to primárně $\mathrm{z}$ důvodu jeho přispívání $\mathrm{k}$ rozvoji regionů a vytváření pracovních př́íležitostí. Tomuto faktu odpovídá také neustálý kontinuální nárůst využívání služeb cestovního ruchu jako prostředku trávení volného času (Bouchet, Lebrun a Auvergne 2004; Tiago et al. 2015).

$\mathrm{Z}$ tohoto důvodu je nutné věnovat pozornost také oblastem s těmito jevy souvisejícími. A tak je pozornost směřována $\mathrm{k}$ zákazníkům, kteří tyto služby využívají a $\mathrm{k}$ poznávání jejich prání a potřeb. Obecně lze definovat spotřební chování jako studium toho, proč lidé kupují produkty a jakým způsobem o koupi rozhodují (Swarbrooke a Horner 2007). Kasapi a Koc (2012) pak specifikují tento proces pro potřeby cestovního ruchu jako proces skládající se z pěti posloupných kroků: uvědoméní si potřeby / touhy cestovat $=>$ sběr dat a jejich hodnoceni $=>$ rozhodnutí o cíli cesty (mezi alternativami) => príprava cesty a samotná cestovatelská zkušenost $=>$ výsledné hodnocení spokojenosti s cestou. Bernini a Cracolici (2014) zdůrazňují některá specifika ve spotřebním chování, která se v cestovním ruchu objevují. Např́iklad, že muži méně rádi cestují do zahraničí než ženy. I velikost rodiny je faktorem vstupujícím do rozhodování - čím větší rodina, tím větší ochota cestovat, a zároveň tím větší preference domácího cestovního ruchu před zahraničním. Svoji roli hraje také statut hlavy rodiny - pokud se jedná o nezaměstnanou osobu, ochota cestovat bude výrazně nižší.

Důležitým prvkem, prostřednictvím kterého je možné na potenciální zákazníky působit je komunikace. Z výzkumů vyplývá, že tak jako v jiných odvětvích, i v cestovním ruchu se projevují jisté trendy. (Tiago et al. 2015; Kasapi a Koc 2012). Autoři uvádí, že spotřební chování v cestovním ruchu je primárně ovlivňováno devíti faktory, mezi něž patří osobní zkušenost, zkušenost přátel, známých či kolegů, dále katalogy a časopisy, oficiální stránky hotelů a destinací, sociální sítě (Facebook, Twitter apod.), cestovní kanceláře a agentury, média a jiné informační technologie (Kasapi a Koc 2012). Informace pak potenciální zákazníci získávají nejčastěji na internetu, dále od známých, osobně v cestovní kanceláři, telefonicky, $\mathrm{v}$ menší míře poštou či přímo v místě pobytu. (Tiago et al. 2015)

Jedním z trendů, který provází rozvoj cestovního ruchu, je stále častější využívání informačních technologií, což je patrné i z předchozího textu. Cestovní ruch je považován za odvětví závislé na informačních technologiích a internet mu poskytuje platformu pro podporu a výměnu informací (Ho a Lee 2007). Internet tak ve velké míře ovlivňuje spotřební chování zákazníků také v tomto odvětví a umožňuje efektivně získávat informace o spotřebitelích a formovat jejich postoje (Bajpai a Lee 2015). Online zdroje jsou považovány za důležitý zdroj informací napříč všemi generacemi spotřebitelů (Li, Li a Hudson 2013).

Firmy, které realizují svou činnost především na internetu, využívají nejčastěji také internetovou reklamu, jako jeden ze způsobů propagace. V ČR je to dle výsledků Svatošové (2013) 66 \% firem obchodujících na internetu. Cestovní ruch a jeho odvětví se v průběhu prvních desetiletí po vzniku České republiky (1991 až 2002) staly lídrem ve využívání internetu, jelikož dokázaly velmi efektivně komunikovat se stávajícími i potenciálními zákazníky prostřednictvím online kanálů (Zach, Gretzel a Xiang 2010), přestože jejich činnost se stále odehrává také v kamenných pobočkách. 
Nejedná se však pouze o internetovou reklamu jako nástroj komunikace využívaný v cestovním ruchu. Online média zahrnují také komunikaci s využitím sociálních sítí, které zaznamenávají rozmach primárně v oblasti ubytovacích a stravovacích zařízení (Chlebovský a Plšek 2012). Prvotní kontakt se zákazníkem a následnou komunikaci mohou usnadnit elektronické newslettery zasílané na e-mail zákazníkům (Leighann a Judith 2014).

Dalším vhodným nástrojem pak mohou být online recenze a jejich důvěrnější podoba eWOM - electronic word-of-mouth (Sotiriadis a Zyl 2013; Zhang et al. 2010; Santos 2014). Předtím, než se zákazník rozhodne o cílové destinaci, hotelu či restauračním zařízení, má možnost přečíst si recenze ostatních zákazníků, kteří toto místo již navštívili a o svoji zkušenost se podělili at' už na webových stránkách, na webech specializovaných na recenze v odvětví cestovního ruchu či na firemních profilech na sociálních sítích (Ye et al. 2011; Vermeulen a Seegers 2009). Tato místa se tak stávají populárnějšími mezi spotřebiteli a pozitivní recenze kladně ovlivňují i takové aspekty, jako je návštěvnost webových stránek restauračních zařízení či počet online rezervací učiněných přes webové stránky ubytovacích zařízení (Zhang et al. 2010; Xiang et al. 2015; Királová a Pavlíčeka 2015). eWOM je pak považován za důvěryhodný zdroj, protože představuje formu recenze od někoho blízkého či známého, komu zákazník důvěřuje a jeho názor pro něj hraje důležitou roli (Xiang et al. 2015).

\section{Metodika}

V průběhu měsíce dubna a května 2017 byl proveden průzkum mezi potenciálními klienty cestovních kancelárí se zaměřením na pobytové zájezdy u moře. Celkem bylo osloveno 50 respondenti̊ ve věku 19-50 let metodou focus groups. Respondenti, kteří se průzkumu účastnili, byli předem dotazováni, zda se účastní pobytových zájezdů u moře a jsou tedy potenciálními klienty cestovních kanceláří, která tento produkt nabízí.

Focus groups byly zaměřeny na spotřební chování zákazníků při výběru pobytového zájezdu u moře a také na oblast moderních nástrojů marketingové komunikace, jelikož kontinuální výzkum se zaměřuje na využití moderních nástrojů marketingové komunikace. Tento průzkum je jednou z dílčích částí výzkumu. Šetření se zaměřovalo na několik oblastí:

- jak probíhá proces výběru dovolené u moře,

- kdo rozhoduje o dovolené,

- kdo hledá informace,

- kde hledá informace,

- co je rozhodujícím faktorem při výběru dovolené.

- kde je nejčastěji registrována „reklama“ (resp. jakákoliv forma marketingové komunikace) spojenou s letní dovolenou u moře,

- které nástroje považují respondenti za moderní nástroje marketingové komunikace,

- jaké nástroje by měly cestovní kanceláře používat, aby respondenty oslovily,

- co by mělo být obsahem sdělení

- a jakou by mělo mít sdělení formu.

Rozhovory byly nahrávány a následně zpracovány. Při zpracování výsledků byly respondenti rozděleny do dvou skupin, aby bylo následně možné porovnat, zda a př́padně jak se odlišují jejich odpovědi. Do skupiny 1 byli zařazeni respondenti do věku 30 let, kteří ještě nemají vlastní rodinu (tzn. bud' žijí s rodiči, sami nebo s partnerem). Do skupiny 2 pak byli zařazeni respondenti, kteří již mají vlastní rodinu. 


\section{Výsledky průzkumu}

První oblastí průzkumu, která byla pro potřeby článku zjišt’ována, se zabývala samotným rozhodovacím procesem respondentů při výběru letní pobytové dovolené u moře. $Z$ hlediska marketingové komunikace a aplikace jednotlivých nástrojů je tato oblast důležitá $\mathrm{z}$ toho důvodu, aby bylo možné marketingovou komunikaci správně cílit.

$\mathrm{V}$ případě respondentů, kteři ještě nemají vlastní rodinu (dále skupina 1), o výběru dovolené nejčastěji rozhodují přátelé, partneři nebo rodiče (zde se jedná o věkovou skupinu cca kolem 20 let). Naopak u respondentů starších 30 let nebo respondentů s rodinou (dále skupina 2) rozhoduje nejčastěji partnerka/manželka/partner/manžel nebo rozhodují o výběru doma všichni společně.

Obě skupiny se liší také v tom, kdo informace o dovolené hledá. Zatímco skupina 1 hledá informace společně, zatímco u skupiny 2 vyhledává nejčastěji informace respondent sám nebo je vyhledává partnerka/manželka. Nejčastějším zdrojem informací o letní dovolené je pro obě skupiny jednoznačně internet, webové stránky konkrétních cestovních kancelárí a následně doporučení od př́átel a známých.

Rozhodujícím faktorem při výběru letní dovolené je u obou skupin shodně na prvním místě cena, dále pak rozsah služeb (a s tím související poměr cena/výkon). U skupiny 1 je pak na dalším místě možnost vyžití v místě a teprve poté následuje zhruba se stejnou četností pohodlí (i v souvislosti s dopravou), bezpečnost destinace a destinace samotná. Na rozdíl u skupiny 2 byla za službami nejčastěji jmenována bezpečnost. Skupina 2 klade větší důraz na bezpečnost destinace než skupina 1 , což může souviset právě s faktem, že jezdí na dovolenou s rodinou a proto je pro ně bezpečnost důležitá. Souhrn jednotlivých faktorů rozhodování pro obě dvě skupiny respondenti̊ je uveden $\mathrm{v}$ Tabulce 1 .

Tabulka 1: Spotřební chování spotřebitelů

\begin{tabular}{|c|c|c|c|c|}
\hline & kdo rozhoduje & kdo hledá informace & kde hledá informace & rozhodující faktor \\
\hline Skupina 1 & $\begin{array}{l}\text { přátelé } \\
\text { partneři } \\
\text { rodiče }\end{array}$ & společně & $\begin{array}{c}\text { internet } \\
\text { web. stránky CK } \\
\text { doporučení přátel a } \\
\text { známých }\end{array}$ & $\begin{array}{c}\text { cena } \\
\text { služby } \\
\text { vyžití } \\
\text { pohodlí/bezpečnost/ } \\
\text { destinace }\end{array}$ \\
\hline Skupina 2 & $\begin{array}{l}\text { partner/ka } \\
\text { manžel/ka }\end{array}$ & $\begin{array}{c}\text { respondent/ } \\
\text { partner } / \mathrm{ka} / \\
\text { manžel/ka }\end{array}$ & $\begin{array}{c}\text { internet } \\
\text { web. stránky CK } \\
\text { doporučení přátel a } \\
\text { známých }\end{array}$ & $\begin{array}{c}\text { cena } \\
\text { služby } \\
\text { bezpečnost }\end{array}$ \\
\hline
\end{tabular}

Zdroj: Vlastní výsledky

Z rozhovorů rovněž vyplynulo, jak probíhají některé rozhodovací procesy při výběru letní dovolené (zejména u skupiny 1). Jak vyplývá i z předchozího textu, skupina 1 klade poměrně velký důraz na možnost vyžití v místě pobytu. Proto i při rozhodování o letní dovolené hraje tento faktor roli. Jako zdroje inspirace při výběru destinace může respondentům ze skupiny 1 sloužit Instagram. Následně si pak dohledají k danému místu informace na internetu a právě možnosti vyžití v místě. Většina ostatních respondentů z této skupiny si pak vyhledává informace na internetu, následně se jdou poradit do cestovní kanceláře a dále dají ještě na doporučení přátel a známých. Obdobná situace se zdroji informací je i u skupiny 2.

Další z otázek zjišt’ovala, kde nejčastěji registrují respondenti "reklamu" spojenou s letní dovolenou u moře. $\mathrm{V}$ kontextu této otázky bylo namísto pojmu marketingová komunikace 
použito vzhledem k lepší představivosti respondentů pojmu reklama, přestože terminologicky správně je marketingová komunikace.

Zde se obě skupiny respondentů v nejčastěji jmenovaných médiích marketigové komunikace shodly. Jednoznačně sem patří komunikace ("reklama") na internetu a v televizi. Skupina 2 komunikaci $\mathrm{v}$ dalších médiích neuvedla. Naopak skupina 1 dále zmiňovala ještě sociální sítě (nejčastěji Facebook a Instagram, v minimálním zastoupení YouTube), kde je nejvíce osloví doporučení od známé osobnosti, poté rádio a zanedbatelné nebyly zmínky ani $\mathrm{v}$ př́padě billboardů a bannerů (bannery by bylo možné zahrnout do samotného internetu, ovšem respondenti jmenovali výslovně bannery, proto jsou uvedeny zvlášt'). S menšími četnostmi pak byly jmenovány noviny a časopisy, komunikace cestovních kancelárí v obchodních domech, doporučení od známých, letáky, e-maily, výlohy CK. Někteří respondenti rovněž uvedli, že si komunikace týkající se dovolené všímají teprve ve chvíli, kdy začínají uvažovat o výběru dovolené. Shrnutí jednotlivých médií za obě skupiny je uvedeno v Tabulce 2.

Tabulka 2: Média, kde respondenti nejčastěji registrují marketingovou komunikaci spojenou s letní dovolenou

\begin{tabular}{|c|c|c|c|c|c|c|c|}
\hline $\begin{array}{c}\text { Média } \\
\text { marketingové } \\
\text { komunikace }\end{array}$ & internet & $\mathrm{TV}$ & soc. sítě & rádio & billboardy & bannery & další \\
\hline Skupina 1 & 19 & 16 & 15 & 11 & 7 & 7 & 11 \\
\hline Skupina 2 & 9 & 8 & - & - & - & - & - \\
\hline
\end{tabular}

Další část focus groups byla zaměřena na téma moderních nástrojů marketingové komunikace, a sice, které nástroje považují respondenti za nástroje moderní marketingové komunikace. Ve skupině 1 na prvním místě převažovaly sociální sítě (konkrétně Facebook a Instagram). Dále pak za moderní nástroje považují mobilní aplikace a překvapivě stále reklama $\mathrm{v}$ televizi a rádio (zde především stanice Evropa 2, Kiss Hády, Blaník, Frekvence 1). I ve skupině 2 byly zmíněny sociální sítě (zde kromě Facebooku a Instagramu byl zařazen také YouTube a Twitter). Dále pak byly jako moderní nástroje označeny reklama na internetu, direct marketing, event marketing a také PR.

Na těchto výsledcích je zajímavé to, že mladší generace respondentů (skupina 1) považuje za moderní nástroje vedle sociálních sítí TV reklamu a rádio, přestože to není kanál, který by je oslovoval (viz výsledky následující otázky). Výsledky jsou shrnuty v Tabulce 3.

Tabulka 3: Nástroje marketingové komunikace, které považují respondenti za moderní nástroje

\begin{tabular}{|l|l|l|}
\hline & Skupina 1 & Skupina 2 \\
\hline $\begin{array}{l}\text { Moderní nástroje marketingové } \\
\text { komunikace }\end{array}$ & $\begin{array}{l}\text { Sociální sítě (Facebook, } \\
\text { Instagram) } \\
\text { mobilní aplikace } \\
\text { TV reklama } \\
\text { rádio }\end{array}$ & $\begin{array}{l}\bullet \begin{array}{l}\text { sociální sítě (Facebook, } \\
\text { Instagram, YouTube, Twitter) } \\
\text { reklama na internetu } \\
\text { direct marketing }\end{array} \\
\bullet \begin{array}{l}\text { event marketing } \\
\text { PR }\end{array}\end{array}$ \\
\hline
\end{tabular}

Zdroj: Vlastní výsledky

Následující otázka byla zaměřena na to, jaké nástroje by měly cestovní kanceláře používat, aby respondenty oslovily. U skupiny 1 to jsou jednoznačně sociální sítě, kde by měly CK podle respondentů sdílet např. zážitky z cest reálných zákazníků. Obsah na sociálních sítích je pro 
skupinu 1 velmi důležitý, což vyplynulo i z dříve uvedených poznatků, že někteří respondenti využívají sociální sítě (především Instagram) jako inspiraci pro výběr destinace. Velmi pozitivně vnímají i sponzorované př́spěvky na Instagramu, které totiž vzhledem $\mathrm{k}$ formátu této sociální sítě nejsou tolik odlišné od příspěvků sledovaných uživatelů. Důležitý je podle respondentů přístup k zákazníkům a reakce na komunikaci (e-maily, telefony, ...). S tím rovněž souvisí recenze, které mohou CK využít ke své propagaci. U skupiny 2 jsou to tradiční nástroje jako barevné katalogy, reklama a věrnostní bonusy.

Co se týká obsahu a jeho formy, tak se obě skupiny shodují v tom, že je pro ně zajímavější vizuální forma komunikace - tedy obrázek nebo video. Skupina 1 by si ovšem v obsahu sdělení představovala především znázornění zážitků a možností vyžití, kdežto skupina 2 by v obsahu sdělení preferovala zdůraznění ceny, bezpečnosti destinace a teprve potom možnost vyžití.

\section{Závěr}

Předkládaný příspěvek se zabýval problematikou spotřebního chování u zákazníků cestovních kancelárí na českém trhu. $\mathrm{V}$ rámci výzkumu byla využita metoda focus groups, pomocí které byl řešen předmět výzkumu a to spotřební chování zákazníků při výběru letní pobytové dovolené u moře. Šetření se zúčastnilo 50 respondentů. Tato technika byla vybrána s ohledem na fakt, že ve výzkumu "měkkých" věd hrají metody kvalitativního výzkumu nezastupitelnou roli.

Autorky se ve výzkumu zabývaly několika kritérii, která jsou při výběru letní pobytové dovolené u moře podstatná, a cílem bylo zjistit, zda jim patřičnou váhu přisuzují i samotní zákazníci. Tato kritéria byla zaměřena na proces výběru dovolené, dále na využití komunikačních kanálů $\mathrm{v}$ rámci marketingové komunikace cestovních kanceláří a na samotné komunikační sdělení - tedy nástroje, prostřednictvím kterých je komunikace registrována, ty které ovlivňují respondenty/zákazníky a co a jakou formou by mělo být těmito kanály komunikační sdělení být předáváno.

Z výzkumu bylo zjištěno to, co odpovídá současným světovým trendům obsažených $\mathrm{v}$ dalších výzkumech zaměřených na tuto oblast, a to fakt, že nejvlivnějšími a nejpoužívanějšími nástroji při výběru dovolené jsou nástroje dostupné prostřednictvím internetu, př́padně sociální sítě (Facebook, Twitter apod.). Velkou roli dle výsledků hraje taktéž tzv. WOM a v cestovním ruchu platí, že osobní zkušenost někoho blízkého (rodina, přátelé, kolegové...), o kterou se s ostatními dotyčný člověk podělí, je ovlivňuje značnou měrou. Jedná se totiž o důvěryhodný zdroj informací. A přesto, že televizní reklama $v$ současnosti ztrácí na své účinnosti $z$ důvodu přesycenosti touto formou komunikace, byla také označena jako jeden ze zdrojů, prostřednictvím které zákazníci informace o destinacích a dovolených získávají.

Předkládané téma je velice aktuální, v českém prostředí mu však není věnována dostatečná pozornost a také po bližším zkoumání problematiky je možné odhalit velký potenciál pro další výzkumy.

\section{Poděkování}

Tento článek vznikl za podpory grantu - "Využití nových marketingových trendů pro zvýšení výkonnosti firem ve vybraných oblastech ekonomiky" registrovaného u Interní grantové agentury FaME UTB IGA/FaME/2016/009 a „VGS 2017K01 Analýza vztahů a vazeb mezi podniky, zákazníky, veřejnou správou a občany“ registrovaného na Soukromé vysoké škole ekonomické Znojmo. 


\section{Literatura}

[1] BAJPAI, A. and CH-W. LEE, 2015. Consumer behavior in e-tourism services: a case of Taiwan. Tourism and Hospitality Management. 21(1), 1-17.

[2] BERNINI, C. and M. F. CRACOLICI, 2015. Demographic change, tourism expenditure and life cycle behavior. Tourism Management. Elsevier, 47, 191-205. ISSN 0261-5177.

[3] BOUCHET, P., A. M. LEBRUN and S. AUVERGNE, 2004. Sport Tourism Consumer Experiences: A Comprehensive Model.: A Comprehensive Model. Journal of Sport \& Tourism. Routledge, 9(2), 127-140. ISSN 14775085.

[4] HO, C. I. and Y. L. LEE, 2007. The development of an e-travel service quality scale. Tourism Management. 28(6), 1434-1449.

[5] CHLEBOVSKÝ, V. and V. PLŠEK, 2012. Research on Czech firms' marketing communication based on social media networks. Acta Univ. Agric. Silvic. Mendelianae Brun. Brno: Mendel University Press, 60(7), 111-118. ISSN 2464-8310.

[6] KASAPI, I. and M. KOC, 2012. Changing Tourism Consumer Behavior: The Impacts on Tourism Demand in Albania. Creative and Knowledge Society. 2(2), 16-34. DOI: 10.2478/v10212-011-0023-3. ISSN 1338-5283. Dostupné také z: http://www.degruyter.com/view/j/cks.2012.2.issue-2/v10212-011-0023-3/v10212-0110023-3.xml

[7] KIRÁL'OVÁ, A. and A. PAVLÍČEKA, 2015. Development of Social Media Strategies in Tourism Destination. Proceedings of the 3rd International Conference on Strategic Innovative Marketing (IC-SIM 2014). 175, 358-366. DOI: http://dx.doi.org/10.1016/j.sbspro.2015.01.1211. ISSN 18770428. Dostupné také z: http://www.sciencedirect.com/science/article/pii/S1877042815012719

[8] LEIGHANN, N. and M. JUDITH, 2014. Using winery web sites to attract wine tourists: an international comparison: an international comparison. Intl Jnl of Wine Business Res. Emerald, 26, 2-26. DOI: 10.1108/IJWBR-07-2012-0022. ISSN 17511062. Dostupné také z: http://dx.doi.org.proxy.k.utb.cz/10.1108/IJWBR-07-2012-0022

[9] LI, X., X. (R.) LI and S. HUDSON, 2013. The application of generational theory to tourism consumer behavior: An American perspective. Tourism Management. Elsevier, 37, 147164. ISSN 0261-5177.

[10] MRÁČEK, P., J. VESELÁ and R. ZICH, 2012. Co-creation in the Image Development in Car Industry: Possibilities and Limits. TRENDY EKONOMIKY A MANAGEMENTU. 6(12), 114-127. ISSN: 1802- 8527.

[11] SANTOS, S., 2014. 2012 \& 2013 Social Media and Tourism Industry Statistics. Dostupné také z: http://www.stikkymedia.com/blog/2012-2013-social-media-and-tourism-industrystatistics

[12] SOTIRIADIS, M. and C. ZYL, 2013. Electronic word-of-mouth and online reviews in tourism services: the use of twitter by tourists: the use of twitter by tourists. Electronic Commerce Research. Springer Science \& Business Media B.V, 13, 103-124. DOI: 10.1007/s10660-013-9108-1. ISSN 13895753.

[13] SURYNEK, A., R. KOMÁRKOVÁ a E. KAŠPAROVÁ, 2001. Základy sociologického výzkumu. Praha: Management Press, 160 s. ISBN 80-7261-038-4. 
[14] SVATOŠOVÁ, V., 2013. Význam internetové reklamy v elektronickém obchodování. Acta academica karviniensia. Karviná: Slezská univerzita Obchodně podnikatelská fakulta v Karviné, (4), 180-192. ISSN 2533-7610.

[15] SWARBROOKE, J. and S. HORNER, 2007. Consumer behaviour in tourism. 2nd ed. Boston: Butterworth-Heinemann. ISBN 978-075-0667-357.

[16] TIAGO, M. T. P. M. B. et al., 2015. Baby boomers turning grey: European profiles. Tourism Management. 54, 13-22. ISSN 0261-5177.

[17] UNWTO Annual Report 2013 [online], 2014. Madrid: World Tourism Organization [cit. 2017-11-02]. Dostupné z: http://www2.unwto.org/publication/unwto-annual-report-2013

[18] VERMEULEN, I. E. and D. SEEGERS, 2009. Tried and tested: The impact of online hotel reviews on consumer consideration: The impact of online hotel reviews on consumer consideration. Tourism Management. Affiliation: Department of Communication Science, Faculty of Social Science, VU University, De Boelelaan 1081, 1081 HV Amsterdam, Netherlands; Correspondence Address: Vermeulen, I.E.; Department of Co, 30, 123-127. DOI: $\quad 10.1016 / \mathrm{j}$. tourman.2008.04.008. ISSN 02615177. Dostupné také z: http://www.scopus.com/inward/record.url?eid=2-s2.0-

$56649111315 \&$ partnerID $=40 \& \mathrm{md} 5=12 \mathrm{f} 64 \mathrm{f} 507 \mathrm{a} 2 \mathrm{e} 37 \mathrm{f} 5 \mathrm{c} 505 \mathrm{ebaca} 955889 \mathrm{f}$

[19] XIANG, Z. et al., 2015. Adapting to the Internet: Trends in Travelers' Use of the Web for Trip Planning: Trends in Travelers' Use of the Web for Trip Planning. Journal of Travel Research. THOUSAND OAKS; 2455 TELLER RD, THOUSAND OAKS, CA 91320 USA: SAGE PUBLICATIONS INC, 54, 511-527. DOI: 10.1177/0047287514522883. ISSN 00472875.

[20] YE, Q. et al., 2011. The influence of user-generated content on traveler behavior: An empirical investigation on the effects of e-word-of-mouth to hotel online bookings: An empirical investigation on the effects of e-word-of-mouth to hotel online bookings. Web 2.0 in Travel and Tourism: Empowering and Changing the Role of Travelers. 27, 634-639. DOI: http://dx.doi.org.proxy.k.utb.cz/10.1016/j.chb.2010.04.014. ISSN 07475632. Dostupné také http://www.sciencedirect.com.proxy.k.utb.cz/science/article/pii/S0747563210000907

[21] ZACH, F., U. GRETZEL and Z. XIANG, 2010. Innovation in the Web Marketing Programs of American Convention and Visitor Bureaus. Information Technology \& Tourism. 12, 47-63. ISSN 10983058.

[22] ZHANG, Z. et al., 2010. The impact of e-word-of-mouth on the online popularity of restaurants: A comparison of consumer reviews and editor reviews: A comparison of consumer reviews and editor reviews. International Journal of Hospitality Management. 29, 694-700. DOI: http://dx.doi.org.proxy.k.utb.cz/10.1016/j.ijhm.2010.02.002. ISSN 02784319.

Dostupné také

$\mathrm{z}:$ http://www.sciencedirect.com.proxy.k.utb.cz/science/article/pii/S0278431910000198

[23] ZICH, R. a J. VESELÁ, 2013. Aplikace technik založených na focus group a skupinové diskuzi při výzkumu vnímání vztahu image a úspěchu podniku: potenciál a limity využití. In: Moderní problémy ekonomiky, podnikání a management: teorie a praxe. s. $221-229$. ISBN 978-5-7526-0597-0. 